\title{
Kasvatustieteilijät: Uskonto tarkastelun kohteeksi!
}

Juha Sihvola (2011). Maailmankansalaisen uskonto. Otava. 399 s.

VOIKO AJATTELEVA ihminen olla uskova ihminen? Käyttämällä omaa elämäänsä esimerkkinä Juha Sihvola vastaa kysymykseensä myöntävästi. Kirjassaan Maailmankansalaisen uskonto Sihvolan apologeettinen viesti kuuluu, että on olemassa uskonnollisuuden muotoja, jotka sopivat ajattelevalle ihmiselle. Kirjoittaja haluaa selventää, että esityksen tavoite ei ole uskonnollinen julistus vaan keskustelu eri vakaumusten edustajien välillä.

Maailmankansalaisen uskonto on tärkeä yritys puhua kahdesta ajankohtaisesta teemasta maallistuneessa maailmassa: uskonnosta ja kansalaisuudesta, ennen kaikkea niiden julkisesta roolista. Sihvola jatkaa teoksessaan Maailmankansalaisen etiikka (2004) tuttua määrittelyä maailmankansalaisuudesta, joka perustuu ihmisyyden eri puolien kunnioittamiseen ja kaikkien ihmisten ehdottomaan tasa-arvoon. Tuoreimmassa teoksessaan hän pääsee katsomuksellisten kysymysten käsittelyssä pitkälle, mutta lukukokemuksena uusin julkaisu ei taida yltää edeltäjänsä veroiseksi.

Sihvola aloittaa hieman katalogimaisen teoksensa filosofisella pohdinnalla fiksun ihmisen mahdollisuuksista uskoa Jumalaan sekä uskon ja moraalin suhteen selvittelyllä. Johdonnossa kirjoittaja onneksi toteaa lukijan alkuinnostuksen lässähdystä estäen, että tuhdin teoreettisiin kysymyksiin tottumaton voi lukea teosta myös muussa kuin esitysjärjestyksessä. Kirja sisältää kaikenkaikkiaan viisi lukua, joiden alla uskontokysymystä käsitellään sekä suomalaisesta että kansainvälisestä näkökulmasta.

\section{"HUUTOMERKKI UMPISEKU- LAARIN KASVATUSTIETEEN MAAILMASSA"}

Kirjoittaja marssittaa esiin useita esimerkkejä uskontoa koskettavista yhteiskunnallisista kysymyksistä. Monet näistä ovat aikaansa seuraavalle lukijalle tosin tuttuja, mutta mukana on kuitenkin suomalaisen mediatiedon ulkopuolelle jääneitä tapauksia sekä tunnettujen aiheiden taustojen syventelyä. Teosta voi pitää huutomerkkinä umpisekulaarissa kasvatustieteen maailmassa, jossa uskonnosta ei voida puhua vakavasti. Se että kasvatustieteen kontekstissa edelleen harrastetaan valikoivaa historiankerrontaa useiden kasvatukseen liittyvien käsitteiden suhteen on vakava osoitus itsekritiikin puuttumisesta sekä toisaalta kulttuuri- ja historiatietoisuuden vähyydestä.

Kirjoittaja puhuu uskonnosta kriittisesti mutta kunnioittaen.
Kirjoittajalle rehellisyys on sitä, että ongelmat tuodaan esille, mutta myös se, mihin hyvään uskonto on pystynyt. Kirjoittaja pyrkii välittämään aidosti sitä, mikä on uskonnon perimmäinen viesti - seikka joka hukkuu helposti asenteellisen ja uskontofobiaisen median kynsissä. Sihvolan tyyli käsitellä aihetta edustaakin itse moniarvoisen demokraattisen keskustelun ihannetta. Teksti on kiihkotonta, vaikka rumat asiat todetaan rumiksi ja kannanottoja tehdään reippaasti. Tunnetulla filosofilla on taito kirjoittaa suurelle yleisölle kepeällä tavalla; kieli kantaa kevyeksi raskaatkin käsitteelliset kysymykset.

Sihvola tulee luoneeksi hyvin tietynlaisen kuvan hyväksyttävästä uskonnollisuudesta, joka voisi sopia sivistyneelle ihmiselle. Hajuttoman, mauttoman, sisällöiltään siloitellun uskonnonko? voisi kysyä. Hän kytkee erilaisten katsomusryhmien toiminnan kehyksen ihanteeksi rawlsilaisen poliittisen liberalismin perinteen, joka suhtautuu kuitenkin positiivisesti uskontojen kontribuution yhteiskunnallisiin kysymyksiin. Sihvola ruoskii patrioottisen, konservatiivisen, ehdottomuuksiin ja kirjaimelliseen tradition tulkintaan perustuvan uskonnollisuuden jos ei aivan Rawlsin "järjettömiin” katsomuksiin, 
niin ainakin moniarvoisen diskurssin marginaaliin. Paikoin Sihvola äityy vallan runolliseksi välittäessään kirjansa perusviestiä: "Ajattelevan ihmisen uskonto on ilon ja ihmettelyn mutta myös kuolevaisen elämään olennaisesti kuuluvan kauhun uskontoa." (s. 86)

Kirja sisältää aimo annoksen aate- ja kirkkohistoriaa. Filosofin teologinen viitseliäisyys ja harrastuneisuus on ilahduttavaa. Paneutuminen teologisiin taustoihin antaa kirjoittajalle uskottavuutta puhua tämän päivän maailmankansalaisuuden uskonnollisista kiinnikkeistä.

\section{SUVAITSEVAISUUS LÄNSIMAI- SESSA AATEHISTORIASSA}

Sihvola pitää kiinni parjatun suvaitsevaisuuden käsitteen hyödyllisyydestä. Suvaitsevaisuus ei Sihvolan mukaan ole hyväksymistä muttei myöskään torjumista. Hän näkee vaivaa käsittteen määrittelyssä, sillä koko suvaitsevaisuutta käsittelevä luku on vaikuttava kavalkadi länsimaista aatehistoriaa. Tällä hän haluaa osoittaa jatkumon, joka uskonnollisen suvaitsevaisuuden kannattamisen historiassa on vallinnut. Tämä onkin ristiriitojen ajan kyllästämässä maailmassa kunnioitettava tehtävä.

On tahdikasta (ja harvinaista!), että kirjoittaja purkaa lukijalle auki oman kantansa ja sitoumuksensa uskontoon heti johdannossa. Omaelämäkerrallisen narraation myötä teosta on huomattavasti helpompi tulkita ja arvioida, eikä se suinkaan vähennä sen "uskottavuutta"; päinvastoin, se vahvistaa kirjoittajan viestiä. Paikka paikoin se tosin luo uskontojen suhteen valistuneelle lukijalle tunteen "sihvolalaisuudesta" pakottaen jättämään hänen subjektiiviseksi arviokseen tietyt luokittelut esimerkiksi suomalaisten uskonnollisten ryhmien kuulumisesta fundamentalistisiin liikkeisiin.

\section{USKONNON KIELI HYLKII RATIONAALISTA}

Sihvola toistaa kirjassaan ajatusta uskonnon kielestä, joka ei ole aukaistavissa rationaaliselle järjen kielelle vaan uskonnolliselle kielelle on tyypillistä ilmausten epäsuoruus, vihjailevuus, symbolisuus. Uskon kieltä ei voi lähestyä reilulla tavalla erilaisesta kielijärjestyksestä käsin; vaatimus kaiken todellisuutta käsittelevän kääntämisestä sekulaarille kielelle ei ole reilua eikä sekulaarin kielen rajat ole maailman rajat. Tämä "toinen kieli" voi mutkikkuudestaan huolimatta olla kieli, joka kertoo olemassaolon merkityksestä enemmän kuin mikään muu. Länsimaisen maallistuneen perinteen edustajana on hyvä ainakin tiedostaa se, että on miljoonia ihmisiä, joille uskonnon kieli on yhtä todellista kuin sekulaari kieli. Uskonnollisen kielen epäsuoruudessa on kiehtovuutensa sekä tietysti ongelmansa; on tilanteita, joissa on vaarallista ratkoa yhteis- kunnallisia kysymyksiä tuhansia vuosia vanhojen tekstien kirjaimellisten tulkintojen avulla.

Pidän Maailmankansalaisen uskontoa varsin kelpona ajattelun ainesten antajana kasvatustieteilijöille, joiden edustama tieteenala uskontosokeassa paradigmassaan ei ole vielä havahtunut ottamaan tosissaan uskonnon tarkastelua. Sihvolan teoksessa on oivaa materiaalia lähteä rehellisesti purkamaan katsomuksellisten kysymysten ilmenemistä yhteiskunnan kasvatusinstituutioissa. Filosofi kiteyttää kirjan loppulehdillä kysymyksen, joka on ikuisesti ajankohtainen kasvatuksen kysymysten parissa askaroiville:

"Koska ihmisillä on potentiaalia yhtäältä vihaan ja väkivaltaan mutta toisaalta myös kunnioitukseen ja yhteistyöhön erilaisten kesken, olennainen kysymys on, suosivatko kasvatuksen ja kulttuurin instituutiot autoritaarisuutta, lauma- ja heimohenkeä, julmuutta ja nöyryyttämistä vai itsenäistä ja kriittistä ajattelua, suvaitsevaa tietoisuutta kulttuurien ja vakaumusten eroista sekä eläytymiskykyä toisen asemaan ja myötätuntoa ihmisen heikkoutta ja haavoittuvuutta kohtaan." (s. 364-365)

\author{
Saila Poulter \\ KM, tutkija, uskonnon didaktiikan \\ yliopisto-opettaja \\ Helsingin yliopisto
}

Väliotsikot toimituksen 